\title{
コンクリートの圧裂試験に関する基礎研究 \\ FUNDAMENTAL STUDIES ON SPLITTING TENSILE STRENGTH TESTS OF CONCRETE
}

\author{
町田篤 彦* \\ By Atsuhiko MACHIDA
}

\section{1. 序}

圧裂試験は，他の方法に比して多くの利点を有するの で, コンクリートの引張強度を試験する標準試験方法と として, 各国の規淮に取り入れられている ${ }^{1) \sim 31}$. この試 験方法を大別すると，横にねかせた供試体を直接上下か ら載荷する方法と, 供試体と試験機の加圧盤の間に分布 板をはさんで載荷する方法の二種類に分類される．これ らの方法は，広く実用に供されているが，いずれにも， 解明すべき，いくつかの問題点が残されている.

すなわち，分布板を用いない圧裂試験では，供試体の 加圧部は供試体全体が破壊する以前に破壊すると考えら れるが，これが供試体の応力分布状況，供試体の破壊な らびに試験結果，等に及ぼす影響は，早急に解明すべき 重要な問題点である. 分布板を用いる圧裂試験の問題点 もこれと表裏一体をなすものであって，分布板の使用が 上記諸事項に及ぼす影響は解明を急がれる問題点であ る、また，圧裂試験によって引張強度が求められるため には, 材料の特性に限界があると考えられるが，この適 用限界を明らかにすることは，実用上きわめて重要であ る. 圧裂試験におけるこれらの問題点は, すでに公表し た筆者の研究成果によりある程度解明されたが4)，なお， 不十分な点が残されているのである.

本研究は, これらの問題点をさらに明快に解明しよう として行った研究をとりまとめたものであって, 供試体 の破壊の進行状況を高速度撮影によって詳細に検討し, 供試体における応力分布状況の測定結果ならびに破壊直 前におけるひびわれ 発生状況の 観察結果, 等とあわせ て，圧裂試験における供試体の破壊現象の解明を試みる とともにこれをもとに上記の諸問題について論じ,さ らに, 引張強度の圧縮強度に対する比が通常のコンクリ 一トにおけるそれより大きな材料について各種の強度試

* 正会員 工博 埼玉大学助教授 工学部建設基礎工学科
験を行って, 圧裂試験の適用限界を明らかにしようとし たものである.

本研究は東京大学審査学位論文の一部を要約したもの であって，これの実施にあたっては，国分正胤先生より 終始ご懇篤なるご指導を賜り，桶口芳朗先生より，暖い ご指導と適切なご示唆を賜った. また，岡村 甫先生に は適切なご助言をいただいた．実験の実施および結果の 整理にあたっては，佐藤昭七郎氏をはじめとする埼玉大 学建設基礎工学科職員の方々より, 熱心にご協力をいた だいた．なお，本研究に対しては，土木学会より昭和 46 年度吉田研究奨励金を受け，研究の機会を与えられた。

ここに，謹しんで厚くお礼申上げる次第です.

\section{2. 破壊直前までの荷重段階における供試体 の挙動}

分布板を用いない圧裂試験における供試体の挙動に関 しては, すでに公表した，載荷中の供試体におけるひず み性状の試験結果, 弾性論に基づいて計算したひずみ分 布と試験で得られたひずみ分布との比較検討，破壊寸前 まで載荷した供試体におけるひびわれ発生状況の観察結 果等により相当の事項が明らかになった.これらの事項 を略述すれば, 以下のようである。

\section{（1）供試体の応力分布}

圧裂試験中の供試体の端面において, 供試体の中心軸 を含む鉛直面（以下，混乱がない限り載荷面といら）に 沿う面直角方向の引張ひずみを測定し，弾性論による計 算値と比較した ${ }^{5), 6)}$.この結果，測定したひずみは，集 中求心線荷重が載荷されるとした場合の計算值とは一致 せず，むしろ，破壊荷重の $80 \%$ 程度の荷重段階まで, 円周上で供試体直径の $1 / 15(d / 15)$ の分布幅を有する等 分布求心荷重が載荷されるとした場合の計算值によく一 致することが認められた（図一1 参照)。これは，供試 


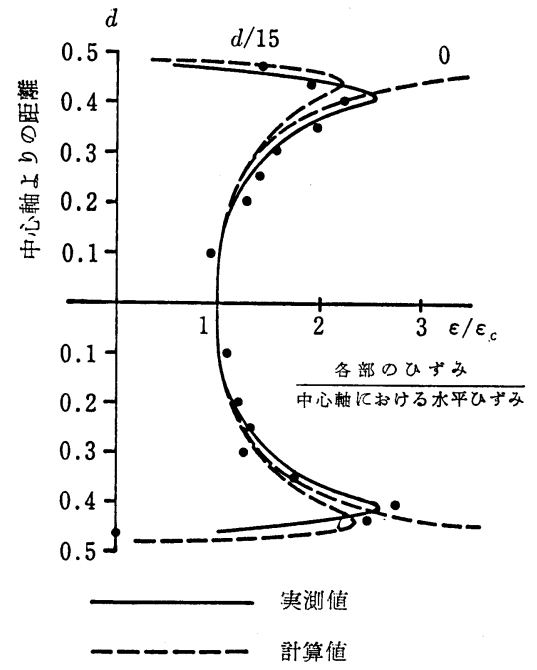

図一1分布板を用いない压裂試験における 供試体の䇅荷面上の水平ひずみの実 測値ならびに計算值

体側面と試験機の加圧盤との接 線（以下，載荷点とい う）における鉛直方向の大きな圧縮応力によってこの近 傍が局部的に破壊し, 荷重がこの局部破壊の幅に対応す る分布幅をもつ分布荷重となるためと考えられる.すな わち，局部破壊によって荷重が集中的に作用し得ないた め, 供試体のひずみも分布荷重が作用する場合の分布状 態となると考えられるのであって, この実験結果は, 供 試体の応力状態も，局部破壊の幅に相当する分布幅の等 分布求心荷重が作用する場合の弾性論による理論応力に 近いことを明示するものである.

弾性論によれば, このような載荷状態の場合, 供試体 の鉛直面における面に直角方向の引張応力は面全域にわ たって一様とはならず, 加圧部に近いある点から加圧部 に向うに従って次第に減少して, ついには圧縮応力とな る. しかし, 荷重の分布幅が $d / 15$ 程度であれば, 供試 体の中心軸 $0.35 d$ の範囲では, この引張応力は一定 とみなしてよく，中心軸を含む鉛直面以外の点における 応力状態も, この範囲で, 集中荷重が作用する場合とほ とんど変化がない. したがって，分布板を用いない圧裂 試験の場合, 破壊荷重の $80 \%$ 程度までは, 供試体の大 部分に集中荷重が作用する場合の理論応力に近い応力が 生じていると考えられる.

以上は, 荷重が破壊荷重の $80 \%$ 程度以下の段階にあ る場合について述べたものであるが, 破壊荷重の 90〜 95\% の荷重段階に至っても, 供試体の中心軸 $0.4 d$ の 範囲においては, 実測したひずみ分布は, 計算値となお よい一致を示した. したがって,この荷重段階に至って も, 供試体の中心部分は弾性的に挙動するのであり, 応 力分布も, これより前の荷重段階におけるそれと大差な
いものと考えられる. しかし, $0.4 d$ 載荷点の範囲にお けるひずみ分布は, この荷重段階では, もはや計算值と のよい一致を示さず, 荷重の増加に対するひずみの増加 の割合が増大した.これは,載荷点における局部破壊がひ ずみゲージを貼付した位置に及んだためと考えられる．

荷重がさらに増大寸ると，（2）で述べる事項により, 供試体の中心軸〜 $0.4 d$ の範囲にも, ひびわれが発生す ると考えられる. 微小ひびわれが発生すれば, それまで この部分で受持たれていた引張応力は他の部分に再分配 されることになるから，この部分における局所的な応力 状態は相当に複雑となる. すなわち, 荷重が破壊荷重の 90〜95\% を越えれば, 供試体の 中心部分の挙動も非弾 性的となり, 供試体のある範囲における平均的な応力状 態を考えても, 弾性論によるものとはある程度は相違す るようになると推定されるのである.

\section{（2）破壊直前の供試体におけるひひわれ発生状況}

破壊に至る寸前の供試体の挙動を明らかにする目的で 破壊直前まで載荷して除荷した供試体にについて，その 端面に発生している微小ひびわれを，顕微鏡を用いて 観察した. この結果, 載荷点近傍には, 載荷面にほぼ平 行な短いひびわれが数多く発生しているが,これらは載 荷点付近に留っていて, 中心部に向って進行している様 子は認められず, 中心部には, これらと独立に, 載荷面 に近くこれとほぼ平行な比較的長いひびわれが発生して いることが認められた. 載荷点付近に数多くのひびわれ が発生するにもかかわらずこれが中心部に向って進展し にくいのは, 載荷点の局部破壊によって荷重が分布荷重 となるため, 載荷面直角方向の応力が載荷点に近い部分

表一1破漛直前の供侙体におけるひびわれ状況

\begin{tabular}{|c|c|c|}
\hline 分+ & $\begin{array}{l}\text { 破塿直前のひびわ } \\
\text { れ数。 }\end{array}$ & 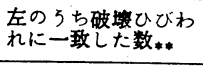 \\
\hline (1) 中心軸 $\sim 0.1 d$ & 26 個（22\%） & 14 個 ( $54 \%)$ \\
\hline (2) $0.1 \sim 0.2 d$ & 18 個 ( $15 \%)$ & 9 個 ( $50 \%)$ \\
\hline (3) $0.2 \sim 0.3 d$ & 22 個 ( $18 \%)$ & 11 個 ( $50 \%)$ \\
\hline (4) $0.3 \sim 0.4 d$ & 22 個 ( $18 \%)$ & 8 個 ( $36 \%)$ \\
\hline (5) $0: 4 d \sim$ 载荷点 & 33 個 ( $27 \%)$ & 7 個 ( $21 \%)$ \\
\hline 計 & 121 個 (100\%) & 49 個 ( $40 \%)$ \\
\hline \multicolumn{3}{|c|}{ 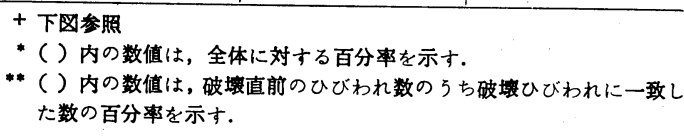 } \\
\hline
\end{tabular}

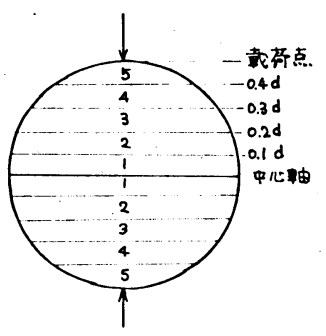


で圧縮応力となることによると考えられる.すなわち， 載荷点付近でひびわれが発生しても，この圧縮応力によ って中心部への進展がさまたげられるものと考えられる のであって, これらのひびわれが破壊の発端となる可能 性は少ないものと思われる.

これらをさらに確めるため, 供試体を再度載荷して破 壊に至らしめ, 供試体端面において破壊時に発生したひ びわれ（以下, 破壊ひびわれという）を求めて, 破壊直 前のひびわれのうちこれと一致したものを選び出した. この結果, 載荷点付近に生じていたひびわれで破壊ひび われに一致するものより, 中央部分のひびわれが破壊ひ びわれに一致する割合が高いことが認められた（表一1 参照).これは, 供試体は中央部分の微小ひびわれが進 展することによって破壊に至ることを示すものであっ て, 載荷点付近は破壊の発端とはなりにくいという上述 の議論を裹付けるものである.

\section{3. 圧裂試験における供試体の破壊性状}

前章で述べたように，すでに公表した事実によって， 分布板を用いない圧裂試験における破壊の寸前までの供 試体の挙動は相当に明らかになったが, 破壊が供試体の どの部分から生ずるか, 破壊の生ずる位置によって示さ れる強度が相違するか，等に関しては，十分に明らかに されたとはいい難い。これを明らかにするために，圧 裂試験中の 供試体の 端面を高速度撮影機を用いて撮影 し, 破壊直前より破壊に至るまでの供試体の挙動につき 検討を加えた. 実験に用いた供試体は, 直径 $15 \mathrm{~cm}$, 高 さ 15〜 $18 \mathrm{~cm}$ のものである. 実験にあたっては，これ の両端面の中心軸に載荷方向と直角方向をなすようひず みゲージを貼付し，ロードセルを介して試験機に据えて 通常の方法と同様に載荷した. 高速度撮影における撮影 時間は一般に短く, 本実験の場合, これが約 1.8 秒に すぎなかったので, この間に供試体の破壊現象を的確に とらえるためには，撮影開始時刻を適切に定める必要が あった．載荷にあたってひずみゲージとロードセルを用 いたのはこのためであって，供試体中心軸における引張 ひずみの荷重の増加に伴う変化を $X-Y$ レコーダーによ って目視し，これが急速に増加する瞬間に撮影を開始し たのである.このようにして撮影した破壊の進行状況を 写真一1 に示す. なお，いかに細心の注意を払って偏心 のないよらに供試体を据えても, 載荷面上の各点のひず みは, 両端面の対応する位置で, まったく等しくはなら ない.このことより, 破壊現象が供試体内部で先行し, 一端面における現象が供試体全体を代表しないおそれが 考えられる.しかしながら, 両端面におけるひずみは, 若干の時間遅れは存在するものの, ほとんど同じ経過を
たどって変化する.したがって，ひずみの変化が先に生 ずる方の端面における現象をとれば，これによって供試 体全体の破壊の進行状況を判断して誤りを生じないもの と考えられる. 写真一1 の結果は破壊が先行した端面に おけるものであって, 撮影したフィルムを, 10〜40 コ マごとに（約 $1 / 400$ 秒〜 4/400 秒ごと）に引き伸したも のである. 高速度撮影の結果から以下のことが認められ た.

(i ) 高速度撮影によって捉えられる最初のひびわれ は，供試体の中心軸を含む鉛直面に近く，中心軸よ゙り大 略 $0.1 \sim 0.15 d$ 離れたほぼ一定の場所に発生する. そ して,このひびわれが認められる時期には, 載荷点付近 にはひびわれはまったく捉えられない. 映画撮影による 場合, 肉眼で発見困難なような微小なひびわれの進展状 況を明らかにすることはできないのは当然であるから， 写真に捉えられていないよらな微小ひびわれが破壊の発 端となっている可能性を完全に否定することはできな い、しかし，撮影にあたって照明を供試体端面に対し約 $30^{\circ}$ の方向からあてたため, ひびわれ内部にはほとんど 光がとどかず，ひびわれは写真上に黒く明瞭に示されて いるのであって, 肉眼で認められる程度のひびわれの進 展状況は，これによって十分明らかにされている.ま た, ひびわれ幅の大小の判定も, 写真に捉えられる範囲 内で, ある程度可能である. それで, 破壊の発端となる ひびわれがあれば, 厳密な意味でのこれの発生の時期か らは遅れるとしても, 写真上にもこれは最初に現われ, 破壊が進行するに従って長さと幅が増大していく状況が 撮影されると考えられる.このことより, 破壊の発端と なるひびわれは, 映画によって最初に認められ, 供試体 の中心軸より $0.1 \sim 0.15 d$ 離れた 部分の 載荷面に近い 位置に生ずるひびわれと考えてよいと思われる.

この結果は, 先に述べた供試体の破壊は載荷点付近に おける局部破壊によって誘発されるものではないという 事実に一致するばかりでなく, 破壊直前のひびわれ発生 状況と破壊ひびわれとの関係より, ある程度予測される 事項とも一致するものである. すなわち, 表一1 の結果 は, 中心軸 $0.3 d$ の範囲に生じた微小ひびわれが破壊 ひびわれに発達する確率が高く, この範囲が破壊の発端 となる可能性の大きいことを示唆しているのである.

2. (1) で述べたように, 圧裂試験における供試体の大 部分には, 相当に高い荷重段階まで, 幅が $d / 15$ の分布 荷重が載荷されるとして弾性論によって計算した応力に 非常に近い忘力が作用している. それで, 供試体に理論 応力に等しい応力が作用していることを仮定すれば，二 軸方向の応力を受けるコンクリートの破壊強度に関する 研究成果によって, 供試体中のもっとも破壊を生じやす い位置をある程度推定できる，供試体の中心軸を含む鉛 


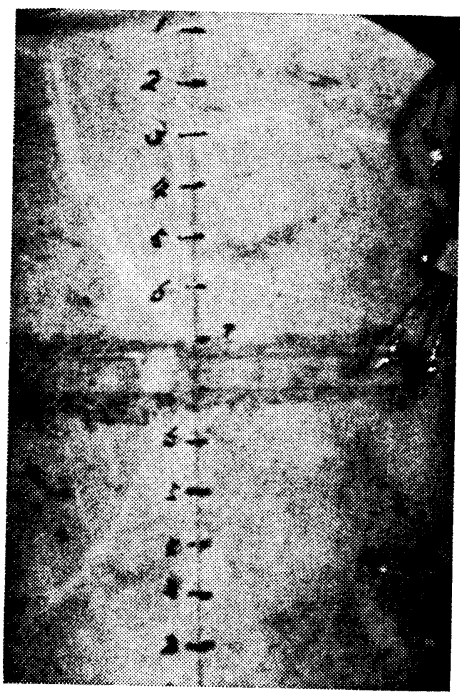

(1)ひびわれ発生を認める.

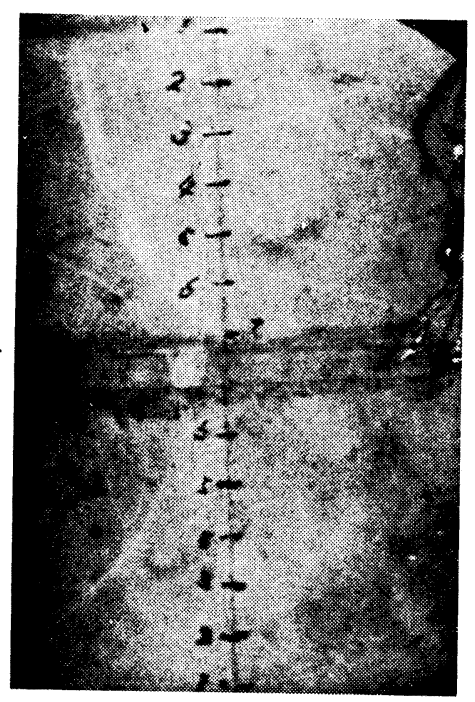

(7) $7 / 400$ 秒後

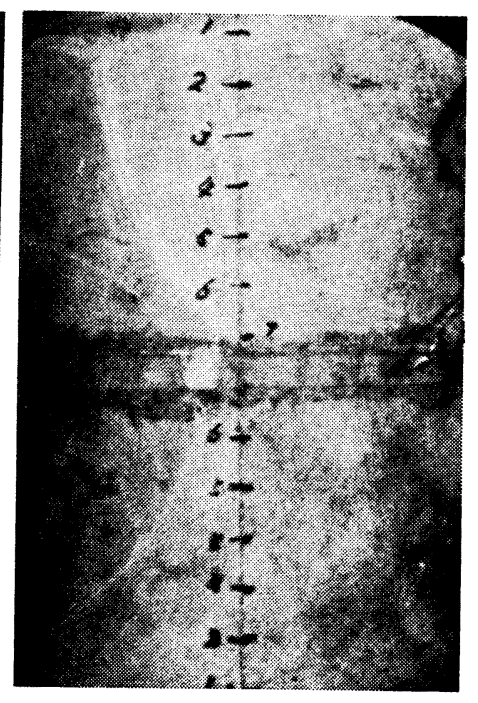

(2) $1 / 400$ 秒後

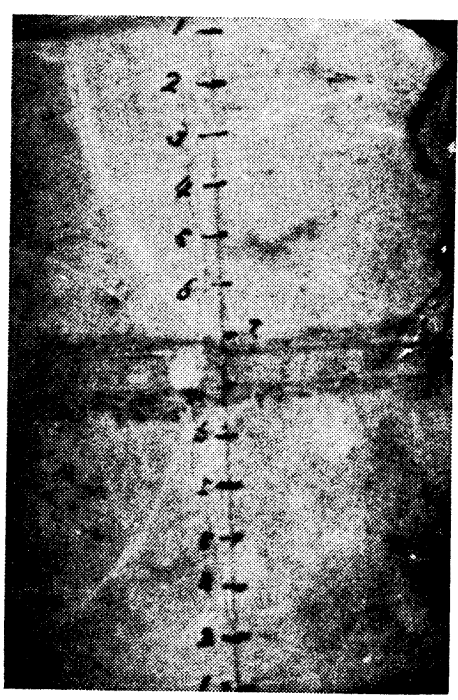

(8) $11 / 400$ 秒後

ひびわれが載荷点間で連続する.

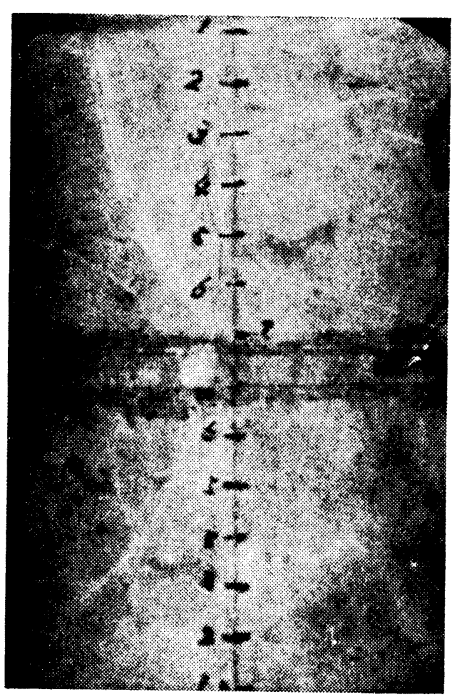

(3) $2 / 400$ 秒後

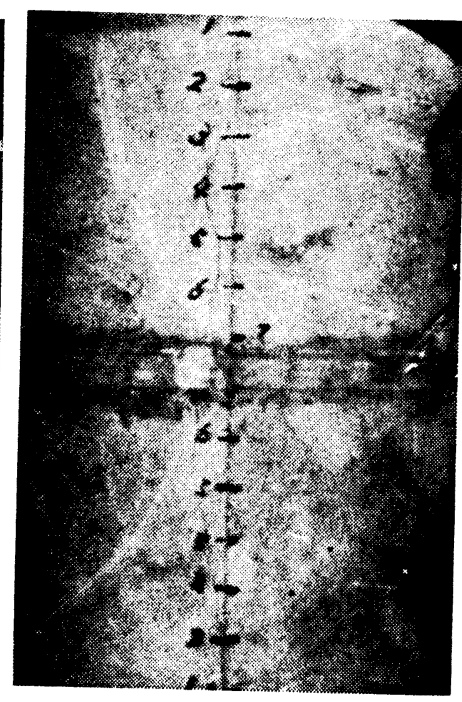

(9) $15 / 400$ 秒後

写真-1 高速度撮影の

直面に沿う，面直角方向の引張応力および鉛直方向の圧 縮応力の計算值は, 図一2 の如くであって, コンクリー トには, 鉛直面上の各点においてこの図で示される大き さの二軸方向の応力が生じていると考えてよい. このよ うなコンクリートの破壊強度は, 数多くの研究成果が公 表されているが, H. Kupper らの成果 ${ }^{7}$ がもっとも信 頼すべきものと考えられる. H. Kupper らの成果のう ちコンクリートの圧縮強度が $315 \mathrm{~kg} / \mathrm{cm}^{2}$ に対するもの を用い (図一3 参照), 載荷面上の各点に打ける破壊強 度と中心軸におけるそれとの比を求めれば，図一2にあ わせて 示した如くなる. $315 \mathrm{~kg} / \mathrm{cm}^{2}$ のものを用いたの は, 本実験で用いたコンクリートの強度がこの程度であ ることおよび H. Kupper らの成果によれば各応力状態
の破壊強度の比には, 圧縮強度によって大きな差が認め られないことによる.これによれば，ある点における破 壊強度がこの点に作用している引張応力を下まわる程度 がもっとも著しいのは，0.4〜0.35dであるから，この 範团がもっとも破壊を生じやすいと推定できるのであ る. しかし, この結果は, 高速度撮影の結果とは一致し ない.この理由は, 図一2 の結果が載荷面の応力状態の みに基づくものであって, 載荷面を離れた部分の応力状 態を考慮に入れていないところにあると思われる.すな わち, 弾性論によれば, 載荷面を離れた部分における引 張ならびに圧縮応力の減小の程度は, 中心軸から載荷点 に向うに従って著しくなる. それで,この応力の減少の 程度からは, より均等な応力状態にある中心軸に近い部 


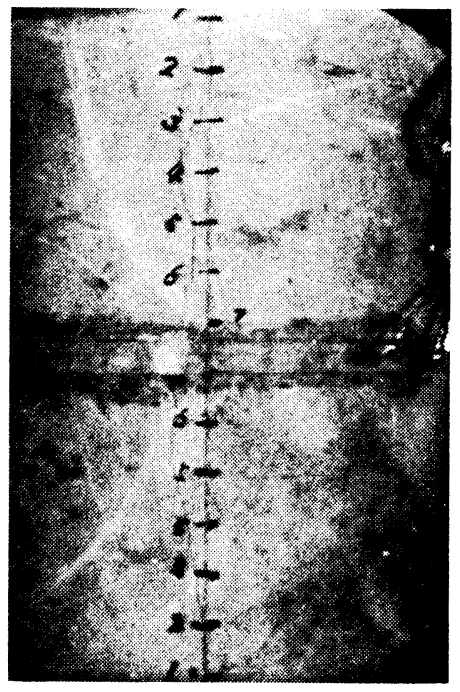

(4) $3 / 400$ 秒後

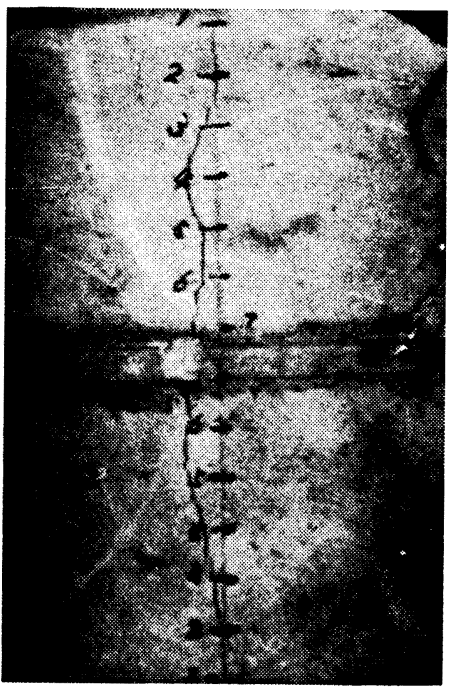

(10) $19 / 400$ 秒後

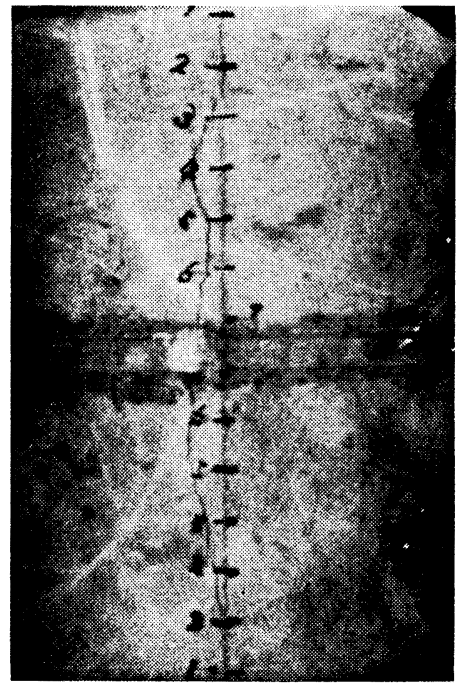

(5) $4 / 400$ 秒後

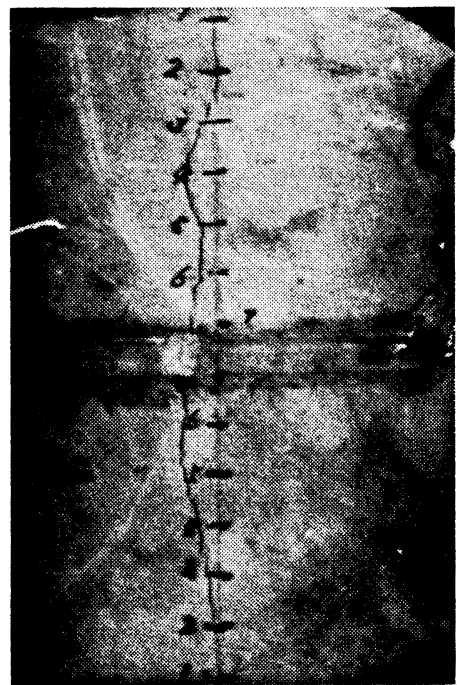

(11) $23 / 400$ 秒後

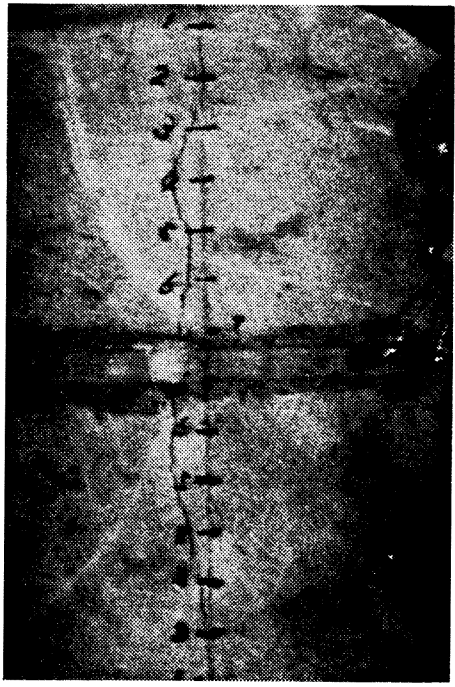

(6) $5 / 400$ 秒後

写真上の数字は, 供訊体の載荷面に 沿5両载荷点よりの距離走 $\mathrm{cm}$ 単位 て示したるので晾る。

結果（分有板なし）

分の方が $0.35 \sim 0.4 d$ 付近より 破壊しやすいといえる のである. 前述のように, 供試体には破壊直前の段階で すでにひびわれが生じているから，供試体の応力状態は 弾性論によるものと異なっている. したがって, 上記の 議論を破壊時にそのまま適用し得ないのは当然である. しかし, 高速度撮影の結果は, もっとも破壊を生じやす い部分が中心軸より $0.1 \sim 0.15 d$ 離れた載荷面付近に あることを示しているのであって，上記の議論をある程 度裏付けているのである.

（ii） 最初に認められるひびわれは，時間の経過に伴 ってその幅が増大するとともに，上下の載荷点に向って 進展寸る.このひびわれが認められてから，大略 $1 / 400$ 〜2/400 秒経過すると, 他の部分に, 最初のものと連続
しないひびわれが認められるようになる。これが最初の ものによって誘発されたひびわれか，これと独立のもの かは, 写真より判定することが困難であるが，これが認 められるまでの時間が最初のひびわれの進展の速さに比 べて短かいので，おそらく独立に生じたものと思われ る.しかし, 写真より明らかなように, 後に認められた ひびわれの進展状況は最初のものに比べて顕著でないか ら，供試体の破壊の進行にもっとも支配的な影響を及ぼ すのは,最初に認められるひびわれであると考えられる。

さらに時間が経過すれば，別の部分にもひびわれが認 められるようになり, いずれも, 上下の載荷点に向って 進展する. そしてついにはすべてのひびわれが連続し， 載荷点の近傍に到達して破壊に至るのである. 最初のひ 


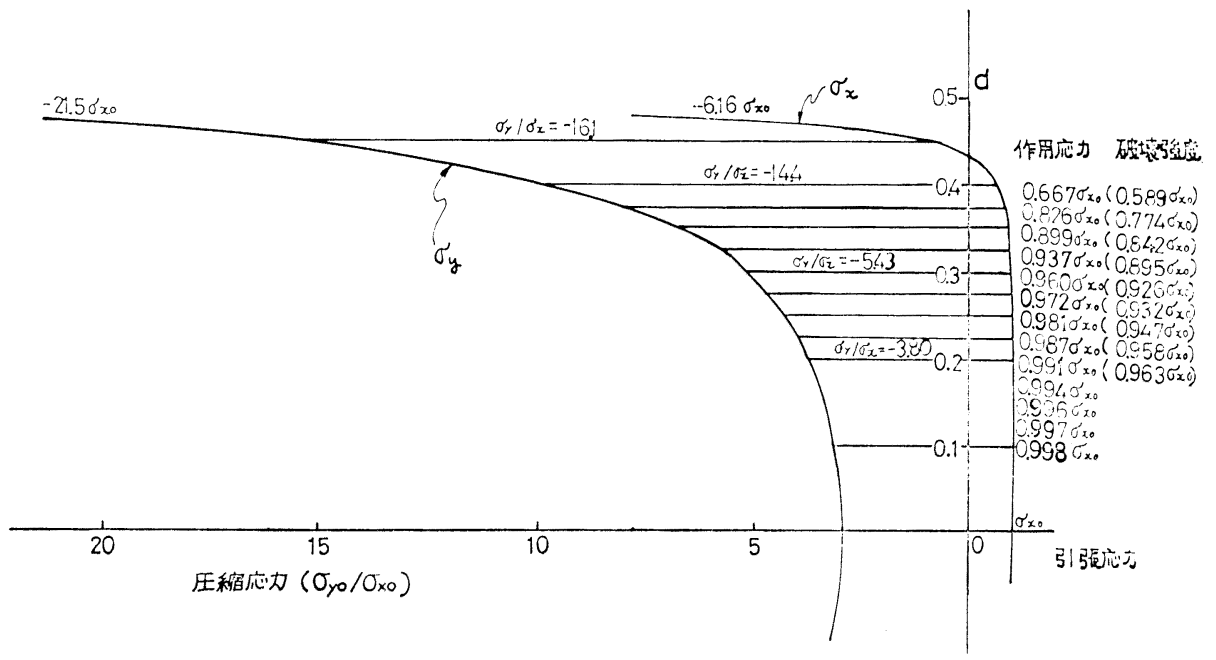

図一2 分布板を用いない圧裂試験における供試体の載荷面上の応力分布ならびに破壊強度

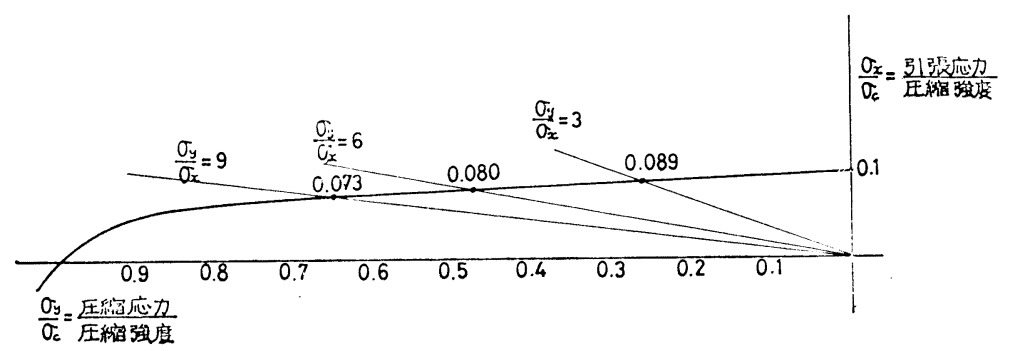

図一3 二軸応力状態のコンクリートの破壊強度")

点から約 $1 \mathrm{~cm}(1 / 15 d)$ 離れた 円周上から発生し, 中央部分に 向って進展するひびわれが認め られる. 圧裂試験を行った供試 体の載荷点付近が非常に複雑な 破壊状況を示し，この部分が破 壊の発端となるといら誤解を招 きやすいのは, この種のひびわ れが発生することが主因と考え られる.上記のように,この種

びわれが認められたのち，これが載荷点に到達するまで の時間は供試体によっていくぶん異なるが, 本実験の場 合, 約 7/400 16/400 秒であってきわめて短い.

上記のようなひびわれの進展状況に, 破壊直前にすで に微小なひびわれが発生している事実を考えあわせる と, 圧裂試験における供試体の破壊は, 想象以上に漸進 的であるといえる. しかし, 最初のひびわれが認められ てから他の部分に別のひびわれが認められるまでの時間 およびひびわれが上下の載荷点間で連続するまでの時間 がきわめて短いことは, 高速度撮影によって認められる 程度のひびわれが発生する段階では, 供試体の載荷面に 近い各部分では破壊にきわめて近く, 耐荷力を失う寸前 の状態となっていることを示すものであって，分布板を 用いない圧裂試験では，ひずみ速度を制御することなく 荷重を増加させる場合, 巨視的には，供試体全体が同時 に破壊すると考えて䛊りではないものと考えられる.

（iii）供試体の中央部分にひびわれが認められる段階 では, 載荷点付近にひびわれが認められない事実は, 破 壊が相当に進行しても変化ないのであって, ひびわれが 載荷点間に連続する段階でも, 載荷点付近に別のひびわ れ恃認められない。しかし,この段階以後になると, 載荷
のひびわれが発生するのは破壊過程の相当後期, すなわ ち, 供試体全体が圧裂荷重に対する耐荷力を失って, 左 右に分離する直前である. すなわち, この種のひびわれ は破壊に伴ら二次的な作用で発生するのであって, 供試 体の本質的な破壊現象には関係が薄いものと考えられる のである.

\section{4. 供試体の挙動に及ぼす分布板の影響}

日本を除く諸外国では, 供試体と試験機の加圧盤の間 に, 長さが 供試体の長さに等しく, 幅が供試体直径の 1/10 1/6 程度の合板その他をはさんで載荷する方法を 圧裂試験の標準方法として規定している. 分布板を使用 すれば, 試験中の供試体の挙動は前章までで述べたこれ を使用しない場合と相当に相違すると考えられるので, 分布板を用いた場合の供試体の挙動に関してさまざまな 角度より検討した。

\section{（1）分布板の使用が供試体中の応力分布に及ぼす影 響}

厚さ $3 \mathrm{~mm}$ 扩よび $10 \mathrm{~mm}$, 哔 $d / 10$ 扩よび $d / 5$ の合 


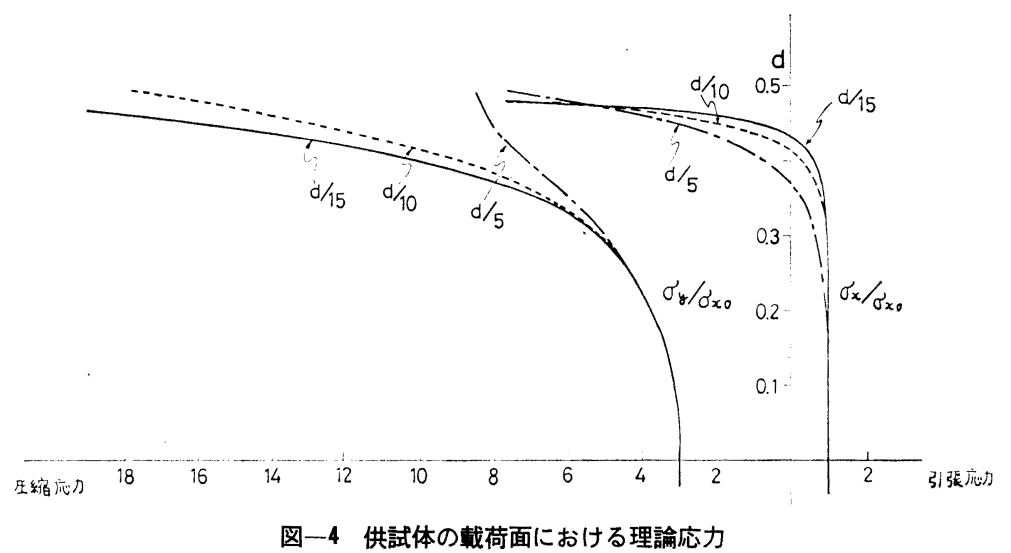

体の応力分布の相違は, 弾性論 による計算応力によって比較す ることができる. 荷重の分布幅 が相違する場合の供試体各部の 応力の計算結果は, 図一4 およ び 図一5 に示すようである. これによれば, 以下の事項が認 められる。

（i）荷重の分布幅が増大し ても, 載荷面に直角の水平方向 の引張応力は, 中心軸の位置で は変化しない.しかし, これに 等しい一様な引張応力の生ずる
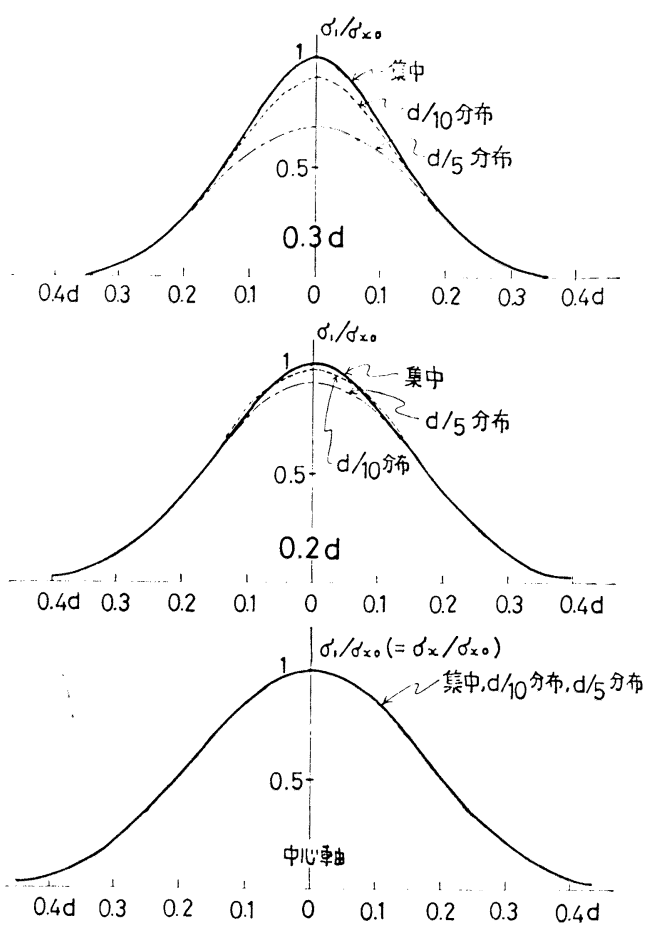

図一5 供試体の水平面上の理論引張主応力

板（普通合板の農林規格を満足する一類合板でラワン合 板）を分布板として用いて圧裂試験を行い，供試体端面 において, 載荷面上の各点の水平ひずみを測定した結 果, 測定したひずみは, 荷重が破壊荷重の $80 \%$ 程度ま では，分布板の幅に等しい分布幅の等分布荷重が作用す るとして弾性論によって計算したひずみによく一致する ことが認められた ${ }^{4)}$ 。このことは, 分布板を用いる圧裂 試験においても，荷重が破壊荷重に近くない範囲では， 供試体の挙動は弾性体に近いことを示すものであって, これにより，供試体に生じている応力も，弾性論による 計算値に近いものと考えられる.したがって, 分布板を 用いる圧裂試験とこれを用いない圧裂試験における供試
範囲は, 荷重の分布幅が増大寸るに伴って減少し, 載荷 点近くで圧縮応力に変化する範囲が増大する.これは, 分布板を用いる圧裂試験とこれを用いない圧裂試験の応 力分布における重要な相違点である.

（ii）載荷面上のこれと鉛直方向の圧縮応力も, 中心 軸においては, 荷重の分布幅にかかわらず一定であるが, 中心軸から載荷点に向らに従ってこの応力が増大する程 度は, 分布幅が大きくなるに従って減小する.

（iii）載荷面を離れた部分に打ける主引張応力は, 分 布幅が増大するに伴ってより一様となる. すなわち, 主 引張応力は, 載荷面を離れるに従って減少するが, その 程度は, 分布幅が増大寸れば著しくなくなるのである.

荷重が破壊荷重の $80 \%$ を越えた場合, 中心軸より $0.4 d$ 以上離れた 部分において, ひずみの測定値は, 理 論值と相違し, 荷重の増加に伴らひずみの増加量がそれ 以前より増加した. しかし, この程度は分布板を用いな い場合より著しくなく, 分布板を用いる試験方法におけ る供試体の載荷点に近い部分の挙動は, これを用いない 場合に比べて,より弾性的であることがうかがわれた。こ の加圧部の挙動に関する相違は, 上記の載荷方向の圧縮 応力の相違によるものと考えられる. しかし, すでに述 べたように, 分布板を用いない圧裂試験の場合, 加圧部 が弾性的に挙動しないことは試験結果に悪影響を及ぼさ ないから,この相違はそれほど重大視する必要はないも のと思われる.

\section{（2）分布板の使用が供試体のひびわれ状況に及ぼす 影響}

幅 $d / 10$ および $d / 5$ の分布板を用いて圧裂試験を行 い, 供試体の破壊直前におけるひびわれ発生状況を, 2. （2）に述べたと同様にして観察した結果, 分布板を用い ない場合にみられる加圧部の短いひびわれが相当に減少 することが認められた4).これは，(1)に述べたように， 分布板を用いれば，加圧部に扝ける載荷方向の庄縮忍力 
が減少するとともに，これと直角方问の応力が圧縮とな る範囲も増大するためと考えられるのであって，加圧部 の局部破壊を防止する上で分布板の使用が相当に有効で あることがわかる。しかし，すでに述べたように，加圧 部の 局部破壊は試験結果に悪影響走及ぼさないので女 り，また，幅が供試体直径の $1 / 5$ にも及分布板を用いて も加圧部のひびわれ発生を完全には防ぎ得ないのである から，加圧部の局部破壊を防ぐために分布板を使用する ことは無意味であるといわざる劣得ない，分布板を使用 する意味は，むしろ，供試体の側面に著しい不整がある 場合に，試験誤差を少なくする点にある ${ }^{4)}$.

なお，分布板を用いる圧裂試験においても，加圧部の ひびわれと独立に中心部にもひびわれが生じ，これが破 壊ひびわれと一致する確率が高い。それで，分布板を用 いても，供試体の破壊は中心より生ずるものと考えられ る.（1）に述べた応力分布より考えれば，分布板を用い る試験の方がこれを用いない試験より，加圧部のひびわ れが中心部に向って進展しにくいことは明らかである.

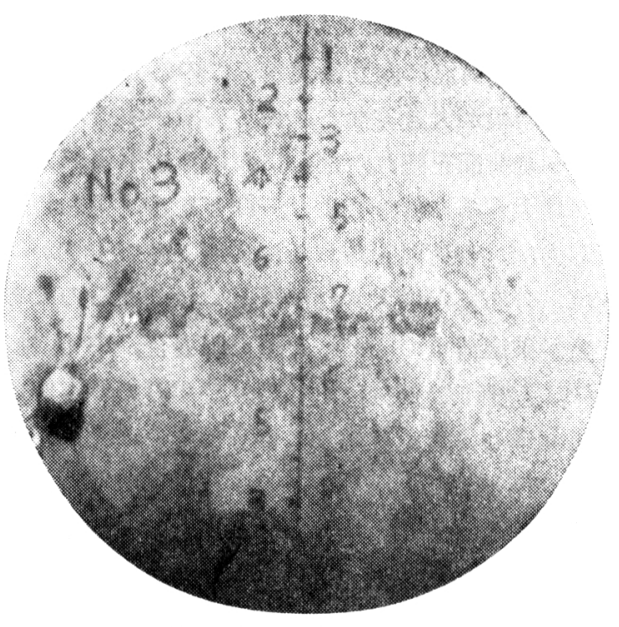

(1)ひびわれ発生を認める.

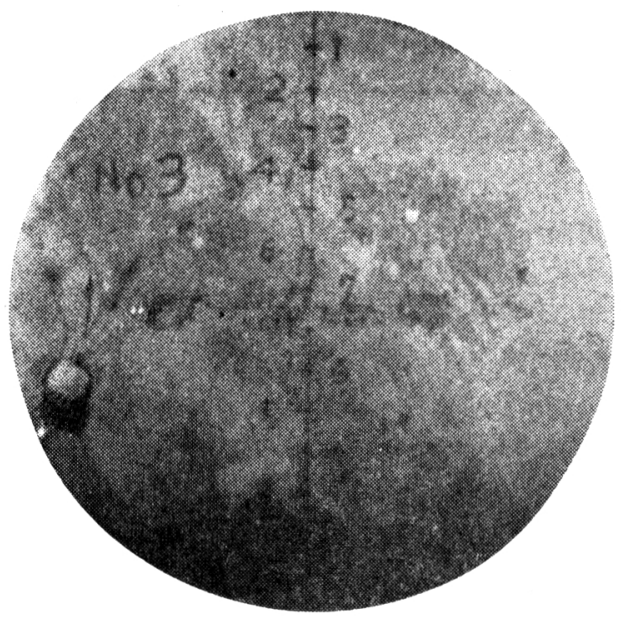

(3) $4 / 400$ 秒後

\section{（3）分布板の使用が供試体の破壊性状に及ぼす影響}

分布板を用いる圧裂試験における供試体の破壊の進行 状況を明らかにするため，3．に述べたと同様の方法で 高速度撮影を行った. 用いた分布板は, 幅 $3 \mathrm{~cm}(=d / 5)$, 厚さ $3 \mathrm{~mm}$ の合板である。撮影されたフィルムを写真 に引伸ばした結果は 写真一2 に示すようであって，こ れより次のことが認められる。

(i) 写真上に最初に認められるひびわれは, 中心軸 より1〜2d 離れた範井に発生している.3.(2) で述べた ように, 写真上で最初に認められるひびわれが最初に発 生したひびわれとは限らないが，このひびわれを破壊の 先導的役割をはたすひびわ机としてよいと考えられる. このように, 分布板を用いても, 破壊の発端となるひび われの発生位置は, これを用いない場合と大差ないので ある。分布板を用いる場合でも，3．に述べたと同様に して, 弾性論および二軸応力状態下のコンクリートの破 壊強度によって, もっとも破壊を生じやすい位置を推定
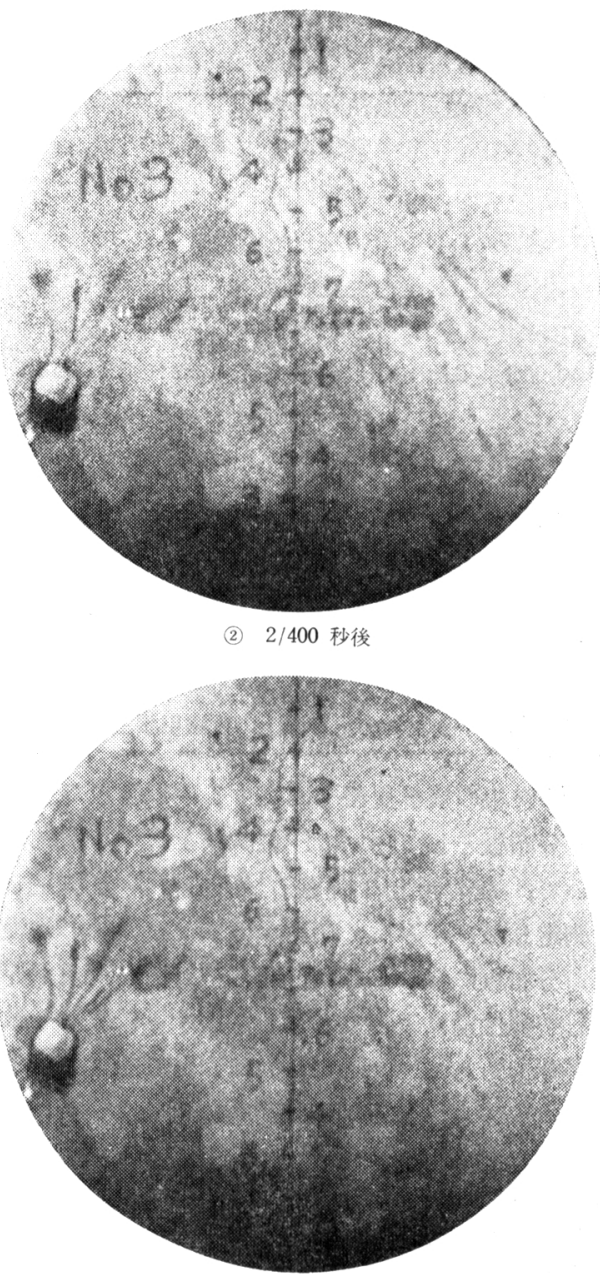

(4) $5 / 400$ 秒後 


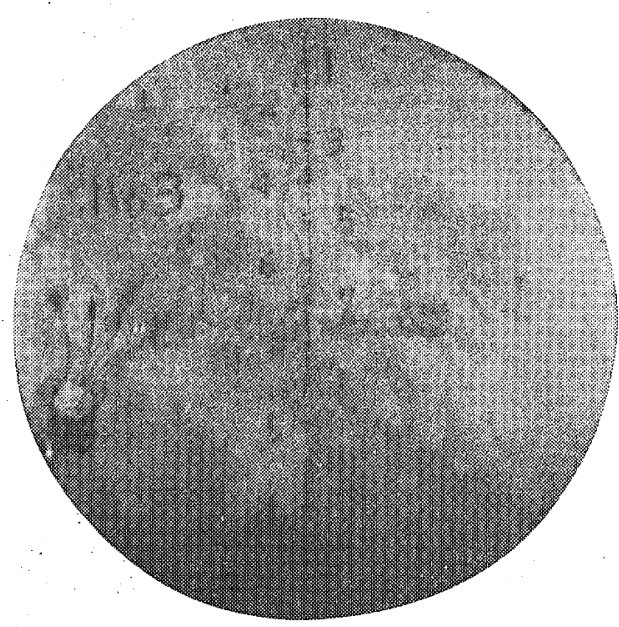

(5) $7 / 400$ 秒後

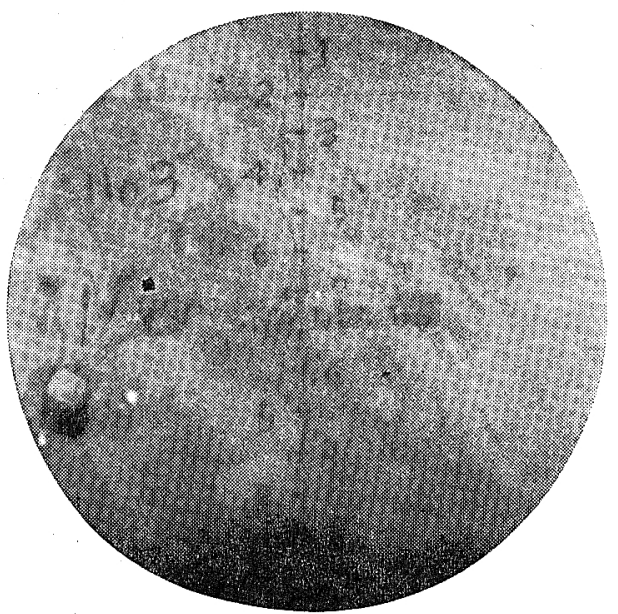

(7) $24 / 400$ 秒後

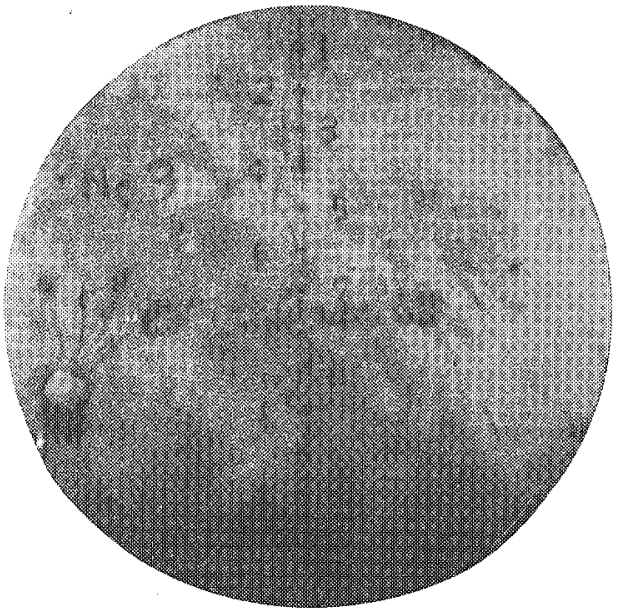

(6) $13 / 400$ 秒後

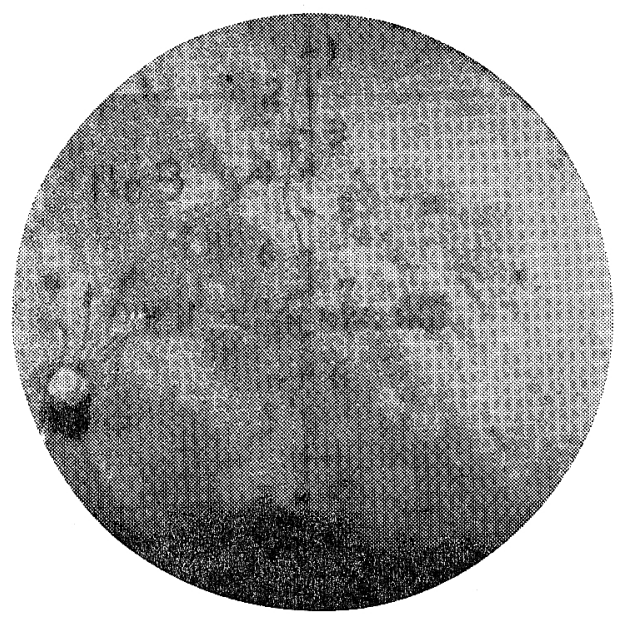

(8) $49 / 400$ 秒後

ひびわれが载荷点間で連続する。

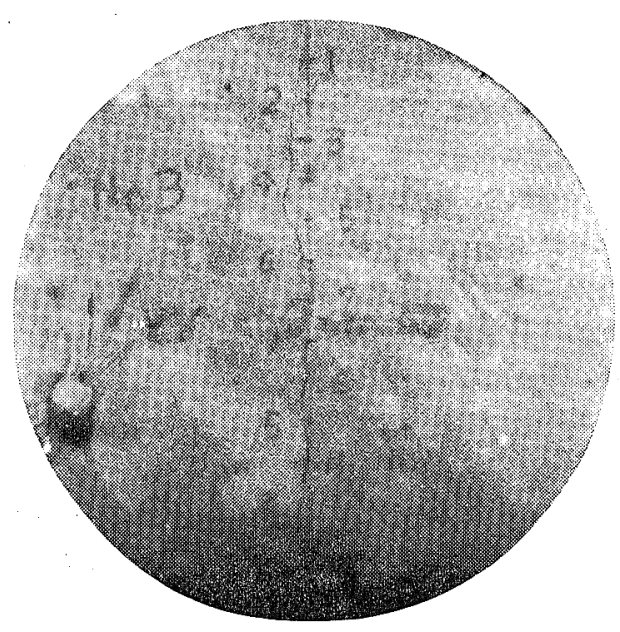

(9) $61 / 400$ 秒後

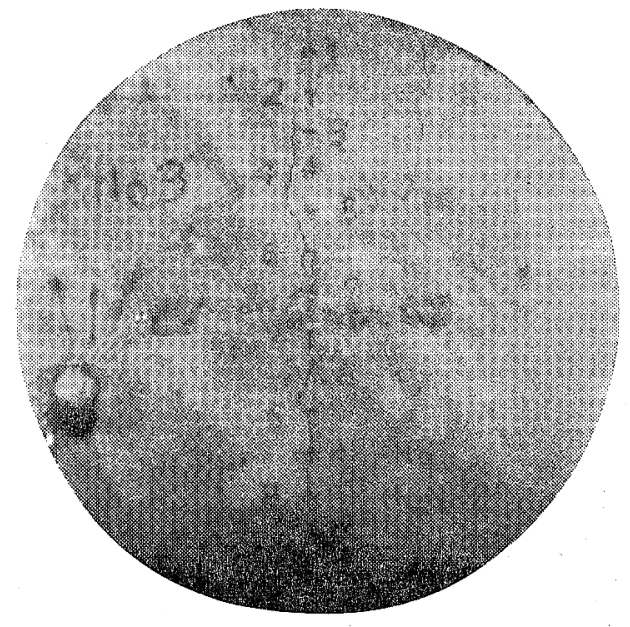

(10) $73 / 400$ 秒後

写真上の数字は，供試体の载荷面に沿う载荷点上りの距離を $\mathrm{cm}$ 単位で示したものである。

写真一2 高速度撮影の結果（分布板を用いる場合） 


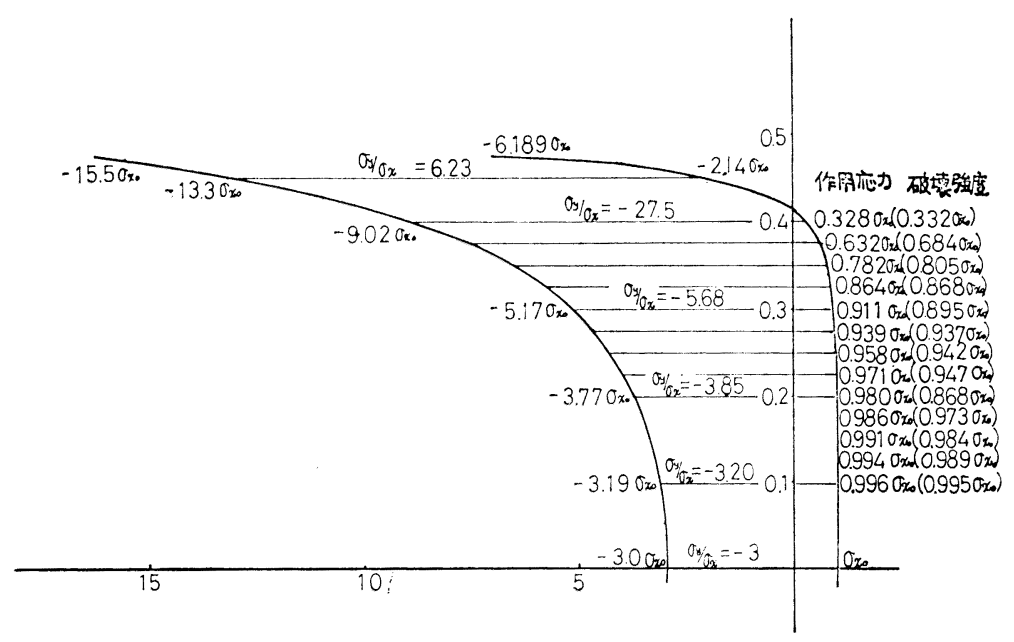

図一6 供試体の載荷面における作用応力と破壊強度の関係 $(d / 10$ の分布板の場合)

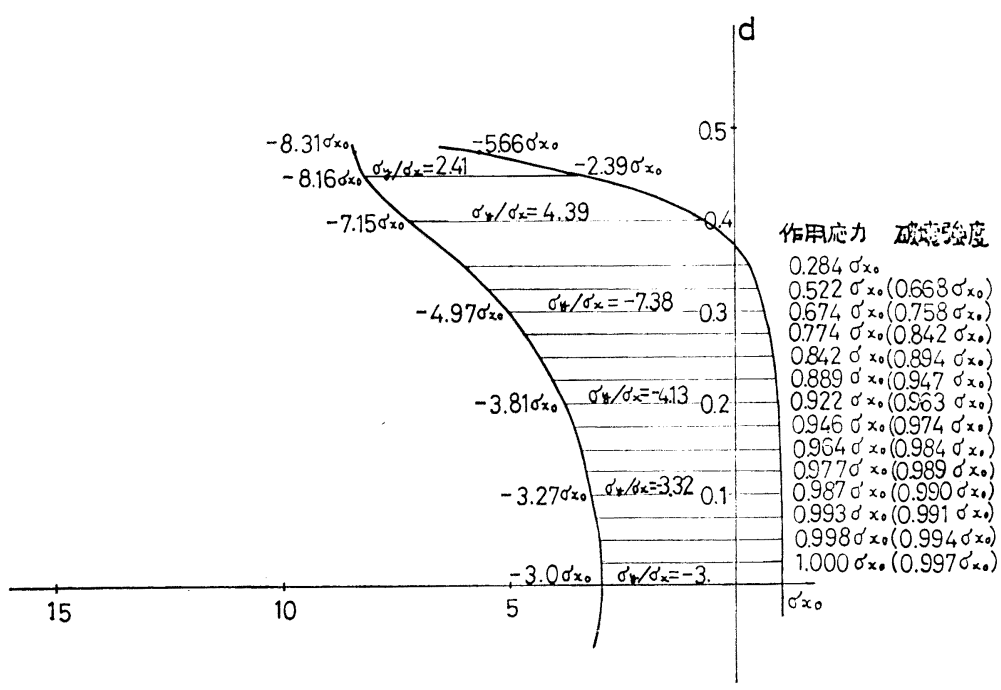

図一7 供試体の載荷面における作用応力と破壊強度の関係 $(d / 5$ の分布板の場合)

できる.この推定の結果は, 図一6 および 図一7 に示す ようであって，破壊がもっとも生じやすい位置は， $d / 10$ の分布板を用いる場合, $0.2 \sim 0.25 d, d / 5$ の場合, 中心 軸 $0.1 d$ の範囲であることがわかる. 本実験に用いた 分布板は，厚さ $3 \mathrm{~mm}$ のものであったから，荷重の分 布幅は $d / 5$ よりいくぶん小さかったと考えられ，した がって，本実験においては，破壊のもっとも生じやすい 位置は，上記の推定よりいくぶん載荷点側に寄るものと 思われる．すなわち，高速度撮影により認められた破壊 の発端となるひびわれの発生位置は，弾性論ならびに二 軸応力状態のコンクリートの破壊強度より推定した位置 とほぼ一致したものと言えるのである.

分布板を用いない場合化破壊の発端となるひびわれの
発生位置が推定と一致しないの にかかわらず分布板を用いる場 合に一致した理由は，載荷面を 離れた部分における主引張応力 の減小の程度の相違にあると考 えられる.すなわち，分布板を用 いる場合, 主引張応力が減少す る程度は, 図一5 に示したよう に，これを用いない場合より著 しくないから，弾性論ならびに 破壊強度によって推定される位 置に最初にひびわれが発生する と，この位置の載荷面を離れた 部分がひびわれ発生によって再 分配される応力を受持つ能力が 低く, 結局これに近い位置で破 壊の発端となるひびわれが発生 するものと思われるのである.

このように, 載荷面をいくぶん 離れた部分が再分配された応力 を受持つ能力の差が，両者の応 力状態に相当な差がみられるに もかかわらず，破壞ひびわれの 発生する位置が大差なくなる大 きな理由と考えられる.

(ii） 最初に認められるひび われは, 時間の経過に伴って, 載荷面にほぼ平行に, 上下の載 荷点に向って進展する.このひ びわれが認められてから，大略 2/400 4/400 秒経過すると， 他の部分にもこれに連続しない ひびわれが認められるよらにな る. 後に認められるひびわれ は，分布板を用いない場合と同様，恐らく最初のものと 独立に発生したものと考えられるが，これの進展は最初 のものに比べて顕著でないから，供試体の破壊の進行に 支配的役割を果たすのは最初のひびわれであると考えら れる.さらに時間が経過すれば，ひびわれが連続して載 荷点の近傍に到達し破壊に至る。このような破壊の進展 状況は，分布板を用いない方法におけるそれと定性的に は大差ないが, 分布板を用いる場合, 最初に認められる ひびわれの進展の速さが分布板を用いない場合と比べて 遅いばかりか，時間の経過に 伴ら幅の増加も著しくな い. 特に, 最初にひびわれが認められてから，上下の載 荷点間にほぼ連続するまでの時間をみると，分布板を用 いない場合,これが約 7/400 秒〜16/400 秒であったの 
に対し, 分布板を用いる場合, 約 25/400 秒 49/400 秒 と大約 2 倍程度となるのである. 破壊の進行状況のこの ような相違は, 両者における供試体載荷面の応力分布の 相違が一因と考えられる.すなわち, 図一2,6，7より， 分布板を用いる場合の方が用いない場合より，二軸応力 をうけるコンクリートの破壊強度が作用する応力より小 さくなる範囲がせまくなることが認められるのであっ て，これが分布板を用いる場合に，ひびわれの進展が遅 くなった原因の一っであると考えられるのである.この ように，分布板を用いる圧裂試験の場合，供試体の破壊 の進展は，これを用いない場合より漸進的であって，供 試体全体が同時に破壊するとみなすことにいくぶんの無 理が感じられる.

（iii） 分布板を用いない場合，ひびわれが載荷点間に 連続すれば，時間をおかず，その幅は顕著に増大する が，分布板を用いる場合，ひびわれ幅の増大はきわめて ゆるやかであって，12/400 秒経過してもひびわれ幅に 大きな差は認められないのである.この抢もな理由は， 分布板を用いる場合，供試体と分布板との間に摩擦が働 き，供試体が左右に分離することを妨げることにあると 考えられる.このことは, (iv) に述べるさらに時間が経過 したのちの供試体の挙動によっても認められる. 供試体 と分布板との間の摩擦が試験結果に及ぼす影響は明らか ではないが, 摩擦力は, 当然, 高速度撮影によって捉え られるようなひびわれが発生する以前にも働いているの であるから，摩擦がない場合に比べてある程度大きな試 験結果を示寸原因になると考えるのが妥当であろう．な 扔, この摩擦力は, ひびわれの進展が漸進的である他の 一つの原因と思われる.

（iv）ひびわれが載荷点間に連続したのち, 載荷点か ら約 $2 \mathrm{~cm}(d / 7.5)$ 離れた 円周上から 発生し, 中央部分 に向って載荷方向とほぼ平行に進展するひびわれが認め られる.この種のひびわれが認められる事実は, 分布板 を用いない場合と同様であるが，その後の進展には相当 の相違がある. すなわち, 分布板を用いない場合, この 種のひびわれは載荷面に沿うひびわれに比べて幅の増加 が著しくないが，分布板を用いる場合，その幅の増加が 著しく, 載荷面に沿うひびわれ以上の幅となる.さら に, 写真には示されていないが, この種のひびわれはそ の後載荷面に向って曲り,ついには載荷面のひびわれに 到達するのであって, 到達した直後に供試体は左右に二 分されて飛び散るのである.このような破壊現象は，供 試体と分布板の間に摩擦力が働き, これが供試体が二分 されるのを防げていることの有力な証明と考えられる. なお，分布板を用いる圧裂試験を行っている場合，供試 体が分布板を用いない場合より急激に左右に分離する現 象がしばしば認められるが，これは，上記のように，供
試体中央部のひびわれが載荷点間に連続し，耐荷力がほ とんど失われた後に起こるものであって，分布板を用い る場合の破壊の進行がこれを用いない場合より急激であ ることを示すものではない，微小ひびわれの発生からひ びわれが載荷点間に連続するまでの破壊現象は，(ii）お よび（iii）に述べたように，分布板を用いる場合のほう がより漸進的なのである.

\section{5. コンクリートの圧裂強度と引張強度との関 係に関する考察}

圧裂試験は引張応力ならびにこれと直角方向より圧縮 応力を受ける二軸応力状態で, かつおのおのの応力の大 きさならびに両者の割合が場所によって大幅に相違する 場合の破壊強度を求めるものであるから, 結果が一様な 引張応力が一方向から作用する純引張強度と相違するの は当然である，それにもかかわらず，従来より，分布板 を用いない圧裂試験の結果は, 通常の品質のコンクリー トについて試験する場合, 純引張試験の結果とほぼ一致 することが認められている ${ }^{8)}$.これまでに述べた事項に よれば, この理由がある程度推定できる.

高速度撮影の結果によれば, 圧裂試験の供試体は, 分 布板を用いると否とにかかわらず，載荷面上，中心軸よ り $0.1 \sim 0.2 d$ 離れた付近より破壊する. この部分では, 水平方向の引張応力 1 亿対して, 鉛直方向より, $3.2 \sim$ 3.8 程度の 圧縮応力が 作用している (図一2 参照). 図 -3 により, この応力状態におけるコンクリートの破壊 強度と圧縮力がまったく作用しない場合の引張強度と を, 引張強度をもとに比較すれば, 圧縮力が作用する応 力状態では, 引張強度が約 15\% 程度低下寸ることが推 定される.すでに述べたように，破壊にきわめて近い荷 重段階では, 供試体の応力状態は微小ひびわれの発生に よって図一2 と相違していること, および 図一3 の結 果はあらゆる強度のコンクリートに対して成立つもので はないこと, 等により, 上記の $15 \%$ は概略の值を与え るにすぎないことはいらまでもない.しかし, 微小ひび われの発生から破壊に至る時間が短いこと，および圧縮 強度が相違しても圧縮応力の作用による破壊強度の低下 の程度には大きな差はないと考えられること, より, 図 -2 および 図一3 が成立つとした仮定は大きな誤りを 生じないと思われる.この考察より, もし, 圧裂試験に おいて供試体の各部が引張応力とこれの直角方向から $3.2 \sim 3.8$ 倍程度の圧縮応力が 作用している一様な応力 状態にあれば, $\sigma=2 P / \pi d l$ によって引張強度を算出す る限り, 純引張試験に比べ大約 $15 \%$ 程度底い強度を示 すとしてよいと考えられる.しかし, 圧裂試験では, 供 試体の応力状態は一様でないから, 圧裂強度と引張強度 
との関係を明らかにするためには, さらに, 二軸応力状 態下のコンクリートの破壊強度に及ぼす応力が一様でな いことの影響を明らかにしなければならない。

分布板を用いない圧裂試験の場合, 高速度撮影の結果 によれば，供試体の中心軸を含む鉛直面上の各点は，ほ ぼ同時にその耐力を失うと考えてよい. したがって，こ の場合には，応力の鉛直方向の分布の影響を考慮する必 要がなく, 水平方向の分布の影響についてのみ考えれば よい. この水平方向の応力分布に限っても, これが破壊 強度に及ぼす影響を明らかにすることは容易ではない が, 曲げ強度試験において, 中央一点載荷法による試験 結果が三等分点載荷法による結果より 20〜25\% 程度大 きくなること, および圧裂試験における載荷面を離れる ことによる応力の減少の程度は曲げ試験の中央一点載荷 法によるそれより著しくないと考えられること，を考え あわせれば, 圧裂試験における破壊が開始する部分の破 壊強度は, 水平方向に応力が減少することが直角方向の 圧縮応力の作用をほぼ相殺し, 純引張強度と大略等しく なることが推定される.それで，分布板を用いない圧裂 試験の場合，前記の如く鉛直方向ではほぼ同時にその耐 力を失うと考えてよいから, 通常の品質のコンクリート について試験すれば, 試験結果は純引張強度に近くなる と考えられるのである.

これに対し，分布板を用いる圧裂試験においては，最 初に破壊を生ずる部分に括ける応力分布状況は分布板を 用いない場合と大差ないが，図一6〜7 に示したように， 載荷面上の応力分布状況は載荷点に向らに従って破壊強 度を下まわる傾向が増している. また, 高速度撮影によ って, 破壊の進展も分布板を用いない場合より漸進的で あることおよび分布板と供試体との摩擦が供試体が二分 されるのを妨げる恐れのあること，が認められている. これらはいずれも, 示される強度が分布板を用いない場 合の強度あるいは純引張強度より大きくなることを示し ている. そして, 分布板の幅が大となれば, 載荷面上の 各点の応力が破壊強度を下まわる傾向が強くなるので, 示される強度も増大すると考えられるのである. 事実, 同じ圧縮強度のコンクリートについて, 分布板を用いな い方法, $d / 10$ の分布板を用いる方法ならびに $d / 5$ の分 布板を用いる方法, によって圧裂試験を行って示される 強度を比較した結果, 分布板を用いる試験方法は, これ を用いない方法と比べて, $d / 10$ の分布板の場合, 3〜14 $\%, d / 5$ の場合 14〜25\% の大きな強度となることが認 められたのである ${ }^{4)}$ このように, 圧裂試験によって示 される強度は, 試験方法によって相違するのであって, 通常の品質のコンクリートについて試験する場合, 分布 板を用いない試験方法によれば, 純引張強度と大差のな い強度が求められると考えられるが，分布板を用いれ
ば，その幅によってはこれより相当に大きな強度が得 られるのである.

\section{6. 圧裂試験の適用限界}

圧裂試験によって材料の引張強度に関する試験ができ る限界について検討するため，合成樹脂エマルジョンを 混和したモルタルについて各種の強度試験を行った. 用 いたエマルジョンは, エチレン-酢酸ビニールコポリマ ーエマルジョンであって, モル比 $0.4: 0.6$, 樹脂分 55 〜 57\% のものである.これを, 七メントと細骨材を重 量比 $1: 2$ で混合したものに所定量混和し, さらに水を 加えて水セメント比 $50 \%$ のモルタルを造って, 7 日間 $21^{\circ} \mathrm{C}$ 水中で養生したのち，21 日間 $21^{\circ} \mathrm{C}$ 湿度 $50 \%$ の 室内に放置して, 圧裂, 曲げ, 引張 (ASTM C-190 に よるいわゆるブリケットを用いた), 圧縮, 等の強度試 験を行った. 試験の結果は 表一2 に示すようであって, これより, 樹脂の混入量が増大するに従い, 圧縮強度は 減少し, 曲げならびにブリケット強度がいくぶん増大し たことが認められる.曲げならびにブリケット強度は材 料の引張特性, 特に引張強度によって定まる強度と考え られるから, エマルジョンの混和によりモルタルの引張

\section{表一2 引張強度/圧縮強度が大となることが 圧裂試験結果に及ぼす影響}

\begin{tabular}{|c|c|c|c|c|c|}
\hline & $\begin{array}{l}\text { 压縮強度 } \\
\text { (右の切片) }\end{array}$ & $\left.\begin{array}{c}\text { 曲计強度 } \\
4 \times 4 \times \\
16 \mathrm{~cm}\end{array}\right)$ & 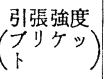 & $\begin{array}{c}\text { 引張強度 } \\
\text { (正裂試験) }\end{array}$ & $\left.\begin{array}{c}\text { 压縮強度 } \\
\phi 5 \times \\
10 \mathrm{~cm}\end{array}\right)$ \\
\hline \multirow{2}{*}{$\begin{array}{l}W / C=50 \% \\
C: S=1: 2 \\
\text { ๑ルタル }\end{array}$} & $\underset{\mathrm{kg} / \mathrm{cm}^{2}}{581}$ & $\frac{83.1}{\mathrm{~kg} / \mathrm{cm}^{2}}$ & 27.7 & $\mid \begin{array}{l}37.7 \\
\mathrm{~kg} / \mathrm{cm}^{2}\end{array}$ & $\begin{array}{l}540 \\
\mathrm{~kg} / \mathrm{cm}^{2}\end{array}$ \\
\hline & 1 & $\begin{array}{c}1 / 6.99 \\
1\end{array}$ & $\begin{array}{c}1 / 21.0 \\
1 / 3.00 \\
1\end{array}$ & $\begin{array}{c}1 / 15.4 \\
1 / 2.20 \\
1.36\end{array}$ & 0.93 \\
\hline \multirow{2}{*}{$\begin{array}{l}W / C=50 \% \\
C: S=1: 2 \\
\text { エマルジョン } \\
=C \times 0.5\end{array}$} & $\begin{array}{l}170 \\
\mathrm{~kg} / \mathrm{cm}^{2}\end{array}$ & $\begin{array}{c}100.9 \\
\mathrm{~kg} / \mathrm{cm}^{2}\end{array}$ & $\begin{array}{l}39.4 \\
\mathrm{~kg} / \mathrm{cm}^{2}\end{array}$ & $\begin{array}{l}33.1 \\
\mathrm{~kg} / \mathrm{cm}^{2}\end{array}$ & $\stackrel{164}{\mathrm{~kg} / \mathrm{cm}^{2}}$ \\
\hline & 1 & $\begin{array}{c}1 / 1.69 \\
1\end{array}$ & $\begin{array}{c}1 / 4.32 \\
1 / 2.56 \\
1\end{array}$ & $\begin{array}{c}1 / 5.01 \\
1 / 3.05 \\
0.84\end{array}$ & 0.96 \\
\hline \multirow{2}{*}{$\begin{array}{l}W / C=50 \% \\
C: S=1: 2 \\
\text { エマルション } \\
=C \times 0.4\end{array}$} & $\begin{array}{l}250 \\
\mathrm{~kg} / \mathrm{cm}^{2}\end{array}$ & $\begin{array}{l}100 \\
\mathrm{~kg} / \mathrm{cm}^{2}\end{array}$ & $\begin{array}{l}36.6 \\
\mathrm{~kg} / \mathrm{cm}^{2}\end{array}$ & $\begin{array}{l}35.9 \\
\mathrm{~kg} / \mathrm{cm}^{2}\end{array}$ & $\stackrel{232}{\mathrm{~kg} / \mathrm{cm}^{2}}$ \\
\hline & 1 & $\begin{array}{c}1 / 2.57 \\
1\end{array}$ & $\begin{array}{c}1 / 6.83 \\
1 / 2.75 \\
1\end{array}$ & $\begin{array}{c}1 / 6.96 \\
1 / 2.81 \\
0.98\end{array}$ & 0.93 \\
\hline \multirow{2}{*}{$\begin{array}{l}W / C=60 \% \\
C: S=1: 2 \\
\text { エマルション } \\
=C \times 0.3\end{array}$} & 259 & $\begin{array}{l}90.7 \\
\mathrm{~kg} / \mathrm{cm}^{2}\end{array}$ & $\begin{array}{l}43.0 \\
\mathrm{~kg} / \mathrm{cm}^{2}\end{array}$ & $\begin{array}{l}43.2 \\
\mathrm{~kg} / \mathrm{cm}^{2}\end{array}$ & $253 \mathrm{~kg} / \mathrm{cm}^{2}$ \\
\hline & 1 & $\begin{array}{c}1 / 2.86 \\
1\end{array}$ & $\begin{array}{c}1 / 6.02 \\
1 / 2.11 \\
1\end{array}$ & $\begin{array}{c}1 / 6.00 \\
1 / 2.11 \\
1.00\end{array}$ & 0.99 \\
\hline \multirow{2}{*}{$\begin{array}{l}W / C=50 \% \\
C: S=1: 2 \\
\text { エマルション } \\
=C \times 0.2\end{array}$} & 432 & $\begin{array}{l}89.4 \\
\mathrm{~kg} / \mathrm{cm}^{2}\end{array}$ & $\begin{array}{l}40.5 \\
\mathrm{~kg} / \mathrm{cm}^{2}\end{array}$ & $\begin{array}{l}53.2 \\
\mathrm{~kg} / \mathrm{cm}^{2}\end{array}$ & $\begin{array}{l}426 \\
\mathrm{~kg} / \mathrm{cm}^{2}\end{array}$ \\
\hline & 1 & $\begin{array}{c}1 / 4.83 \\
1\end{array}$ & $\begin{array}{c}1 / 10.7 \\
1 / 2.21 \\
1\end{array}$ & $\begin{array}{c}1 / 8.12 \\
1 / 1.68 \\
1.31\end{array}$ & 0.99 \\
\hline
\end{tabular}

注）曲げ強度供試体の切片在用いた压縮強度は 12 個の，他圭 6 個の試 験值の平均值を示した。 
強度は圧縮強度に対して相対的に増大したといえる。こ れに対し, 圧裂強度はエマルジョン混和量の増加に伴 って減少している.この圧裂試験の供試体は, いずれの 配合のものも, 最大荷重に達したのち急激に荷重が低下 するとともに，載荷面に沿ってひびわれが上下方向に貫 通して破壊した，破壊は相当に穏やかであって，供試体 が二分して飛び散るといら現象はまったくみられず，破 壊後にもその形状を保つものが多かった。この現象を除 いて供試体の破壊状況を観察する限り，压裂試験によ。 て引張強度が試験できるように思われる。しかしなが ら, 強度試験の結果は, 上記のように, 圧裂強度は引張 強度と正の相関があることを示していない。

前章に述べたように, 通常の品質のコンクリートにつ いて圧裂試験を行った場合に純引張強度と大差のない強 度が得られる理由は, おもに, 圧縮一引張の二軸応力状 態下のコンクリートの破壊強度が 図一3 の如き形状と なり，かつ，破壊が純引張強度と大差のない破壊強度と なる応力状態の部分で生ずることにある.したがって, 破壊強度が 図一3 と相違する材料では圧裂試験によ。 て引張強度を求めることができない，本実験に用いたモ ルタルは, 上記のように, 引張強度が圧縮強度に対し相 対的に増大しているから，これの二軸応力状態下の破壊 強度は, 通常の品質のコンクリートのそれと相当に相違 していると考えられ，それで上記の如き結果が得られた ものと思われる.

表一2 より，エマルジョンを混和したモルタルのう ち, 曲げ強度/圧縮強度 $=1 / 4.83$ のものの場合, 圧裂強 度/曲げ強度 $=1 / 1.68$, 圧裂強度/ブリケット強度 $=1.31$ であって，エマルジョンを混入しないモルタルのそれぞ れに対応する值の $1 / 2.20$ および 1.36 に近いが, 曲げ 強度/圧縮強度 $=1 / 2.86$ 以上になるとこれらの值がエマ ルジョンを混入しない場合と相当に相違していくことが 示されている. 前述のように, 曲げ強度ならびにブリケ ッ卜強度は，おもに材料の引張強度によって定まると考 えられるから,これらに対する圧裂強度の比が大差なけ れば，圧裂強度は引張強度に近いと考えられる．それ で, 表一2 の結果は, 曲げ強度/圧縮強度 $=1 / 4.83$ 以下 の場合には, 圧裂試験を引張強度試験として適用でき, $1 / 2.86$ 以上の場合にはこれが適用できないことを示し ていると思われる.

表一2 と同様の実験を絽返した結果, $4 \times 4 \times 16 \mathrm{~cm}$ の 供試体を用いて中央一点載荷によって試験した曲げ強度 のこの供試体の切片を用いて試験した圧縮強度に対する 比が 1/4.4 1/4.8 になる場合およびブリケット強度の 圧縮強度に対する比が 1/11 1/15 になる場合に, 圧裂 試験を引張試験として適用できなくなることが、示され た.このことから, 曲げ強度ならびにブリケット強度は
引張強度に比例すると仮定して適用限界に達したモルタ ルにおけるエマルジョンを混和しないモルタルに対する 引張強度の増加率を計算し, さらにエマルジョンを混和 しないモルタルの引張強度を圧縮強度の $1 / 11$ と仮定し て, 圧裂試験が 適用できなくなる限界の引張強度/圧縮 強度を求めた結果, 引張強度が圧縮強度の $1 / 6 \sim 1 / 8$ に 達すれば啇用限界となることが認められた。この推定は 大略のめやすを与えるものにすぎない，しかし引張強度 が圧縮強度のたかだか $1 / 6$ 程度で圧裂試験が適用でき なくなることは注目に值するものであって，圧裂試験の 適用範用は意外に広くないことが認められるのである.

\section{7. 結論}

圧裂試験に㧍ける供試体の挙動を，特にその破壊時に おいて詳細に検討し，分布板を用いない圧裂試験におい て従来より問題とされていた加圧部の局部破壊が試験結 果に及ぼす影響を解明しょうとするとともに，分布板の 使用が試験結果に及ぼす影響, 圧裂引張強度と純引張強 度との関係，圧裂試験の適用範囲，等をも明らかにしよ らとした。広く実用に供されている品質のコンクリート に関して，実験の範囲内で次のことがいえると思われ る.

（1）分布板を用いない圧裂試験では，加圧部が局部 的に破壊するため, 従来より指摘されているように, 荷 重は理想的な線荷重とはならず, 分布幅が $d / 15$ 程度の 分布荷重となる. しかし, 加圧部を除く供試体の大部分 は相当に高度の荷重段階まできわめて弾性的に挙動する のであって, その応力状態も, 局部破壊の幅に相当する 分布荷重が作用する場合の弹性論による 理論応力に 近 い. 弾性論によれば，集中線荷重および分布幅 $d / 15$ の 分布荷重が作用する場合の応力状態は大差ないから, 供 試体の大部分に集中荷重が作用する場合の理論応力に近 い応力が生じていると考えられる.また, 荷重が破壊荷 重に近づくにつれ，局部破壊の範囲はいくぶん搪大され るが, 加圧部に生じたひびわれは, 供試体中心部に向っ て進展せず, 供試体はこれと独立に中心部に生じたひび われが進展して破壊する.このように, 分布板を用いな い圧裂試験に拈ける加圧部の局部破壊は, 供試体の応力 状態に悪影響を及ぼさないばかりか, 従来より危惧され ていたような供試体全体の過早な破壊を誘発する抢それ も少ないのである.

（2）高速度撮影の結果, 分布板を用いない圧裂試験 の供試体は, 中心軸より $0.1 \sim 0.15 d$ 離れた載荷面近く に最初の破壊ひびわれが発生し，これが $7 / 400 〜 16 / 400$ 秒というきわめて短時間の間に上下の載荷点間に連続し て破壊に至ることが認められ，また，破壊後にみられる 
加圧部のくさび状のひびわれは, 破壊の終期に二次的に 発生するものであることも認められた. 破壊ひびわれが 最初に発生する位置は, 弾性論によって求めたこの付近 の応力分布および 圧縮一引張の二軸応力状態下のコンク リートの破壊強度より推定される位置とほぼ一致する。 分布板を用いない圧裂試験における供試体の破壊は, こ のように，一部分に発生したひびわれが他の部分に及ぶ といら漸進的なものであるが，最初にひびわれが発生し た直後に他の部分にもこれと独立のひびわれが発生する ことおよびひびわれの進展速度がきわめて早いことよ り，供試体はその載荷面の全域にわたってほぼ同時に耐 荷力を失って破壊すると考えて大きな誤りではないと思 われる. 供試体の載荷面に沿っては, 水平方向の引張応 力はほぼ一様であるが鉛直方向の圧縮応力は相当に変化 するので, 載荷面の破壊強度は各所で相違するはずであ る.それにもかかわらず上記の結果が得られたのは, 載 荷面を水平方向に離れた部分の応力分布をも考慮に入れ れば, 破壊強度が載荷面に沿ってほぼ一様であることを 示すものと思われる.

（3）分布板を用いない圧裂試験においては, 最初に 破壊ひびわれを生ずる部分の破壊強度はその応力状態よ り判断してほぼ純引張強度に等しく, また, 載荷面に沿 ら各部の破壊強度は, 最初に破壊ひびわれを生ずる部分 と大差がないと考えられる.これが，きわめて複雑な二 軸応力状態にあるにもかかわらず，圧裂試験によって純 引張強度と大差のない強度が求められる理由である. ᄂ たがって，(5) に述べるよらに，二軸応力状態の破壊強 度が通常の品質のコンクリートと著しく相違する材料に 対しては, 圧裂強度は引張強度と相関がないが, 通常の 品質のコンクリートの範囲では, 破壊強度を示寸包絡線 の形状に大差はないと考えられるから，圧裂強度はほぼ 純張強度に等しい強度を示すものと考えられる。

従来, 諸外国の例にならって分布板を用いる圧裂試験 を採用すべきとの声もあるが，(1) で述べたように分布 板を用いないことによる悪影響は少なく，(4) で述べる ように, 試験結果に, これを用いることによる悪影響が 及ぼされないのであって, さらに，分布板を用いないこ とによる試験方法の簡便さをも考虑すれば，通常の品質 のコンクリートについて型わくを用いて造った供試体に よって試験する場合, 分布板を用いる試験方法は採用す べきでないと判断される.

（4）分布板を用いる圧裂試験における供試体の破壊 の進行は, これを用いない場合に比べて, より漸進的で あることが認められた。 この理由は，分布板を用いる場 合, 供試体の載荷面に沿う応力が, 載荷点に向うに従。 て, 二軸応力を受けるコンクリートの破壊強度を下まわ る程度が増加すること, および, 分布板と供試体との間
の摩擦が供試体の破壊を妨げること，にあると考えられ る.それで，分布板を用いる圧裂試験によれば，純引張 強度よりいくぶん大きな強度が示されると考えられる. この方法を標準方法として規定してしまえば，大きな強 度が示されること自体はそれほど重大な問題とはならな いが, 分布板を用いれば, 試験が繁雑となるばかりでな く, 上記の結果から予想されるように, 幅のみならずそ の材質についても規定しなければ, 試験結果が変動する おそれも生ずる.また，分布板を用いれば加圧部の局部 破壊を防ぐうえで相当に有効であるが，(1) で述べたよ らに，局部破壊を防ぐ意義は薄い，したがって，分布板 を用いる方法は，一般に，優れた試験方法とはいいにく いと考えられるのである. 分布板を用いて有利となるの は, すでに公表したように，供試体の側面に著しい不整 がある場合に，不整による試験誤差が少なくなる点にあ る.したがって, 著しい不整を避けられない場合には， 分布板を用いて試験することが望まれる.この場合, 示 される強度が分布板を用いない場合と相違することに留 意しなければならないことはいうまでもない。

（5）（3）で述べたように，二軸応力状態の破壊強度 が通常の品質のコンクリートと相違する材料では, 圧裂 試験によって引張強度を求めることはできない，圧縮強 度に対して引張強度を相対的に増加させたモルタルにつ いて各種の強度試験を行った結果, 圧裂試験によって引 張強度を求㧹る限度は, 圧縮強度に対する引張強度の 比が大約 1/6 1/8 であって, これ以上に引張強度の大 きい材料では, 圧裂試験を引張強度試験として適用でき ないことが認められた． 圧裂試験はきわめて優れた試験 方法ではあるが，これを引張強度試験として適用できる 範囲は上記のように意外に狭いから, 通常のコンクリー 卜と強度特性を異にする材料にこれを適用しようとする 場合, 事前の十分な検討が必要とされる.

\section{参 考 文献}

1) JIS A 1113 : コンクリートの引張強度試験方法, 昭和 51 年 3 月.

2) ASTM designation : C 496-66, Standard Method of Test for Splitting Tensile Strength of Molded Concrete Cylinders, 1966.

3) Commision Essais des Ciments et des Bétons : Méthode RILEM pour l'échantielonnage, la Confection, la Consersation et les Essais Mécaniques de Béton, Bulletin RILEM N 30, March, 1966.

4) Atsuhiko Machida: Studies on Tests for Splitting Tensile Strength of Concrete, Proc. of JSCE, No. 242, Oct. 1975.

5) J. Prescott : Applied Elasticity, Dover Publications. 1961.

6）川本朓万：応用弾性学, 共立出版社, 昭和 43 年.

7) H. Kupper, H.K. Hilsdorf and H. Rush : Behavior of Concrete under Biaxial Stresses, Journal, American Concrete Institute, Aug. 1969.

8）内山 実: コンクリートの引張強度とその試験方法につ いて, 鉄道技術研究所彙報, 第 3 巻 5 号, 昭和 19 年 5 月.

(1977.12.19・受付) 